\title{
Semiotic Analysis on Sambyaku Rokujuu Go Nichi no Kamihikouki by AKB 48
}

\author{
Muhammad Iqbal $^{1}$, Nina Alia Ariefa ${ }^{2}$ \\ \{ikubaru022@gmail.com ${ }^{1}$,nina_alia@ui.ac.id $\left.{ }^{2}\right\}$
}

Universitas Indonesia, Indonesia ${ }^{1,2}$

\begin{abstract}
Some lyrics that exist in a certain song, has many implications throughout the lyrics, reviews are needed to reveal the whole meaning, and what form of purposes that occurred in a song lyric. The purpose of this research is to uncover all the meaning that may be found in a song 365 日の紙飛行機 (sambyaku rokujuugo nichi no kamihikouki) by AKB48. The analysis in this research uses the theory of semiotics by Roland Barthes with a research step consisting of disclosing the meaning of denotation, lexia identification, connotation based on lexia, and drawing conclusions. In conclusion, the meaning that contained in the lyrics of the song 365 日の紙飛行機 (sambyaku rokujuugo nichi no kamihikouki) is a story about human efforts to achieve their dreams and hopes in life, and grow through a long process towards success.
\end{abstract}

Keywords: Song Lyrics, Semiotics Roland Barthes, Denotation of Meaning, Lexia, Connotation of Meaning

\section{Introduction}

Song is an inseparable thing from people's lives, in their daily lives people often listen and sing a song. The song is not just for entertainment but the song is also commonly used in traditional ceremonies, respect for the country, in religious rituals. Starting from that was born folk songs, national songs, religious songs and various other types of songs.

Song lyrics are the expressions of the author about something he has seen, heard and experienced. In expressing their experiences, the poet or songwriter makes play on words and language to create attraction and distinctiveness to the lyrics or poetry. Waluyo in Sulkifi [1] explains that poetry is a form of literary work that imagines poets' minds and feelings imaginatively and is composed by concentrating all the power of language on their physical and inner structures. Based on this statement, if we juxtapose song lyrics with poetry, then in song lyrics there are also many implied meanings, as are the meanings in poetry. Furthermore, Wellek \& Warren [2] say's that song lyrics are a message to be conveyed either orally or in writing that has the function to create an imaginative for the listener and have a multiple meaning.

Therefore, a review to reveal the meaning of a song's lyrics becomes important to do to show the ideas that the song writer intends to convey through the lyrics of the song he created.

This study will focus on a review of the meaning of the 365 Nichi no Kamihikouki song lyrics by AKB 48. 


\section{Methodology}

Because the aim of the research is to reveal the meaning of the sign contained in the 365 Nichi no Kamihikouki song lyrics, the right method is the semiotics approach. Semiotics allows us to see the performance of the distribution of signs that form a meaning in a work. In more detail Roland Barthes's theory of semiotics about the two processes of significance. The first stage or first significance is the denotative level. Denotative sign is also a connotative marker, which has entered the second stage or significance. This theory is based on the theory of signs proposed by Ferdinand de Saussure, only the expansion of meaning is carried out with the meaning that takes place in two stages, as shown in the following chart [3].

\begin{tabular}{|l|l|}
\hline 1. signifier & \multicolumn{1}{|c}{ 2. signified } \\
\cline { 1 - 2 } 3. denotative sign & 5. CONNOTATIVE SIGNIFIED \\
\hline 4. CONNOTATIVE SIGNIFIER & \\
\hline 6. CONNOTATIVE SIGN &
\end{tabular}

From the map of Barthes above according to Cobley and Jansz in Sobur [4] it can be seen that the denotative sign (3) consists of a signifier (1) and a signified (2). However, at the same time, the denotative sign is also a marker (4). In other words, it is a material element: only if you recognize the sign "lion", then connotations such as self-esteem, ferocity, and courage become possible. Meaning occurs in two stages. Signs (markers and markers) in the first stage and fused so that they can form markers in the second stage, then in the next stage these markers and markers that have fused can form a new sign which is an extension of meaning

Denotation is the literal meaning, the real meaning that is confused with references or references. Whereas connotation is a meaning that is identical with the operation of ideology which is called by Barthes as a "myth" and serves to reveal and give the real thing of the dominant values that apply in a certain period. What Barthes points out is that the meaning of denotation is the level of signification that explains the relationship between the signifier and the signified in reality to produce a clear, direct and definite meaning, while the connotation meaning is to explain between the sign and the sign in which operates an unclear, indirect and certain meaning [5].

Based on Barthes's semiotic approach, the expression of meaning in the lyrics of this song is carried out with four steps of research. First is to explain the meaning of denotation in the lyrics of 365 songs Nichi no Kamihikouki, then the second is to identify lexia, then to express the meaning of connotation based on lexia, and the final step is to draw conclusions in the form of the meaning of the song's lyrics based on a series of connotation interpretations.

\section{Findings and Discussion}

Here are the song lyrics from 365 Nichi no Kamihikouki from AKB 48 and the denotation reading. A brief description of the meaning of the denotation is shown in the following table:

\begin{tabular}{|l|l|}
\hline 朝の空を見上げて & I see the sky in the morning, \\
今日という一日が & I hope \\
笑顔でいられるように & Order today \\
\hline
\end{tabular}




\begin{tabular}{|c|c|}
\hline そっとお願いした & \\
\hline $\begin{array}{l}\text { 時には雨も降って } \\
\text { 涙も㵋れるけど } \\
\text { 思い通りにならない日は } \\
\text { 明日 頑張ろう }\end{array}$ & $\begin{array}{l}\text { Sometimes it rains } \\
\text { And tears also overflowed } \\
\text { When the day is not as expected } \\
\text { Fighting for tomorrow }\end{array}$ \\
\hline $\begin{array}{l}\text { ずっと見てる夢は } \\
\text { 私がもう一人いて } \\
\text { やりたいこと好きなように } \\
\text { 自由にできる夢 }\end{array}$ & $\begin{array}{l}\text { In the dream } \\
\text { I always see myself alone } \\
\text { Want to do the thing I like } \\
\text { And freely dreaming. }\end{array}$ \\
\hline $\begin{array}{l}\text { 人生は紙飛行機 } \\
\text { 願い乗せて飛んで行くよ } \\
\text { 風の中をカの限り } \\
\text { ただ進むだけ } \\
\text { その距離を競うより } \\
\text { ごう飛んだかどこを飛んだのか } \\
\text { それが一番 大切なんだ } \\
\text { さあ心のままに } \\
365 \text { 日 }\end{array}$ & $\begin{array}{l}\text { Life is a paper airplane } \\
\text { which brings hope flying } \\
\text { drive as much as possible in the wind } \\
\text { rather than comparing the flight distance } \\
\text { better see how and where to fly. } \\
\text { That is the important thing } \\
\text { Always according to conscience } \\
365 \text { days }\end{array}$ \\
\hline $\begin{array}{l}\text { 星はいくつ見えるか } \\
\text { 何も見えない夜か } \\
\text { 元気が出ないそんな時は } \\
\text { 誰かと話そう }\end{array}$ & $\begin{array}{l}\text { How many stars can be seen? } \\
\text { At night who can't see anything } \\
\text { When things are not going well } \\
\text { Talk to someone. }\end{array}$ \\
\hline $\begin{array}{l}\text { 人は思うよりも } \\
\text { 一人ぼっちじゃないんだ } \\
\text { すぐそばのやさしさに } \\
\text { 気づかずにいるだけ }\end{array}$ & $\begin{array}{l}\text { Think about that human again } \\
\text { Not alone } \\
\text { Just never conscious } \\
\text { The good that is next to it }\end{array}$ \\
\hline $\begin{array}{l}\text { 人生は紙飛行機 } \\
\text { 愛を乗せて飛んでいるよ } \\
\text { 自信持って広げる羽根を } \\
\text { みんなが見上げる } \\
\text { 折り方を知らなくても } \\
\text { いつのまにか飛ばせるようになる } \\
\text { それが希望 推進力だ } \\
\text { ああ楽しくやろう } \\
365 \text { 日 }\end{array}$ & $\begin{array}{l}\text { Life is a paper airplane } \\
\text { That brings flying love } \\
\text { The wings that stretch with confidence } \\
\text { Seen by everyone } \\
\text { Even though I don't know how to fold it } \\
\text { Someday it will definitely fly } \\
\text { It is a driver of hope } \\
\text { Let's enjoy } \\
356 \text { days }\end{array}$ \\
\hline $\begin{array}{l}\text { 人生は紙飛行機 } \\
\text { 願い乗せて飛んで行くよ } \\
\text { 風の中を力の限り } \\
\text { ただ進むだけ } \\
\text { その距離を競うより } \\
\text { ぞう飛んだか どこを飛んだのか } \\
\text { それが一番大切なんだ }\end{array}$ & $\begin{array}{l}\text { Life is a paper airplane } \\
\text { which brings hope flying } \\
\text { drive as much as possible in the wind } \\
\text { rather than comparing the flight distance } \\
\text { better see how and where to fly. } \\
\text { That is the important thing } \\
\text { Always according to conscience } \\
365 \text { days }\end{array}$ \\
\hline
\end{tabular}




\begin{tabular}{|l|l|}
\hline さあ心のままに & \\
365 日 & \\
\hline 飛んで行け! & "Fly, \\
飛んでみよう! & just try flying” \\
飛んで行け! & "Fly, \\
飛んでみよう! & just try flying” \\
飛んで行け! & "Fly, \\
飛んでみよう! & try to fly” \\
\hline
\end{tabular}

In the context of dismantling the song lyrics of 365 Nichi no Kamihikouki, the lexia of a textual piece is determined by the need of this research to find the overall meaning in the lyrics of this song. By breaking the song lyric text into chronological order of the lexia text unit, and analyzing the sequence of lexia obtained until the conclusion is drawn. Leksia are units of reading which, if isolated, will have an impact or have a unique function compared to other texts. A lexia can be anything: sometimes in the form of one or two words, sometimes a group of words, sometimes a few sentences, even a paragraph, depends on "easy" - just. Here are the leksia in the lyrics of this song.

1. 朝の空

2. 笑顔でいられるようにそっとお願いした

3. 雨も降って涙も溢れるけじ

4. 夢

5. 人生は紙飛行機願い乗せて飛んで行く

6. 風の中を力の限りただ進むだけ

7. その距離を競うより

8. どう飛んだかどこを飛んだのか

9. 365 日

10. 星はいくつ見えるか何も見えない夜か

11.一人ぼっちじゃないんだ

12. 自信持って広げる羽根

13. 希望推進力

14. 折り方を知らなくても

15. 飛んで行け!飛んでみよう!

The above lexias, when combined with one another, will form a short story that will make it easy to find the meaning of the song.

In lekia 1 朝の空 asa no sora which means morning sky has a connection with lexia 2 笑顔で いられるようにそっとお願いした egao de irareu youni sotto onegai shita means to pray to be able to smile, if combined these two stories tell about lexia pray in the morning sky to be able to smile.

In lexia 3 雨も降って涙も溢れるけど ame mo futte namida afeureru means that even though rain falls and tears overflow, the lexia is related to lexia 1 and 2 that, pray in the morning to smile but rain falls and tears fall sleep. 
And lexia 4 夢 yume means dream. Linkages with lexia 1,2 and 3 pray in the morning so they can smile but rain, tears overflowing and dreaming. Then the four lexia have a connection with lexia 5 人生は紙飛行機願い乗せて飛んで行く jinsei ha kamihikouki negai wo nosete tonde $\mathrm{iku}$, which means life is a paper plane that flies with the hope that the connection is a prayer to smile rain, water the eyes, and dreaming is a part of life

In lexia 6 風の中を力の限りただ進むだけ kaze no naka wo chikara kagiri tada susumu dake has the meaning of going as far as possible in the wind. in this lexia has a connection with lexia 5 which tells the speed of a paper airplane in the wind then the relationship with the previous lexia is hdiup this is a paper airplane that carries smiles, tears, dreams but the paper airplane must still fly forward in the wind.

And then in lexia 7 その距離を競うより sono kyori wo kisou yori rather than comparing the distance has a related to lexia 8 どう飛んだかどこを飛んだのか dou tonda no ka doko wo tonda no $\mathrm{ka}$ 'See how and where to fly'. The connection between these two lexia is not to compare flying distances, but look at how and where they fly. the connection with the previous lexia is not to compare the distance of a paper airplane but look at how and where the paperplane is flying.

Furthermore, in lexia 9365 日 365 nichi means 365 days. In this lexia is related to the 5th lexia which tells the travel time of the paper plane.

Next on lexia 10 星はいくつ見えるか何も見えない夜か hoshi ha ikutsu mieru ka nanimo mienai yoru $k a$ related to lexia number 8 and 9 , these two lexia are the direction projections mentioned in lexia number 8 and the days spent in lexia 9.

In the lexia 11 一人ぼっちじゃないんだ hitori bocchi jyanai means not alone. This lexia has a connection with the 10th lexia which tells about the invisible condition of the stars but it will not be alone.

And then in lexia 12 自信持って広げる羽根 jishin motte hirogeru hane has a meaning, confidently spread your wings wide. Has a connection with the 5th lexia that life is a paper airplane that spreads its wings wide.

Then in lexia 13 折り方を知らなくても orikata wo shiranakutemo means not knowing how to fold it. In this lexia is related to the 5th lexia. Ignorance in folding paper airplanes.

Next in lexia 14 希望 推進力 kibou sushin ryouku has the meaning of the hope driving has something to do with the sixth lexia stepping forward in the wind, if it is reported it will become another driving force for the paper airplane.

Last, in the lexia 15 飛んで行け!飛んでみよう! Tonde ike! tonde miyou! means not knowing how to fold it. In this lexia is related to the 5th lexia. Ignorance in folding paper airplanes.

After identifying lexia, the next step is to reveal the meaning of connotation. 
The reading of connotation is the level of signification that explains the relationship between the sign and the sign in which the implicit, indirect and uncertain meaning operates. The connotation has shifted in meaning because of cultural construction, but still attached to the symbol or sign. This interpretation is based on the lexia found in the verse of the song 365 Nichi no Kamihikouki which will allow the writer to find a meaning. The expressions in 365 Nichi no Kamihikouki's song are represented by lexia 1 through 15 . The whole relationship between expression and denotation will be an expression for layers of connotation that will become meaning.

\section{1. . 朝 $の$ 空}

In the first lexia the expression of denotation meaning is the morning sky. In the connotation layer of connotation, the meaning contained in this lexia experiences a shift in meaning namely, the morning sky is like hope for humans.

\section{2. 笑顔でいられるようそっとお願いした}

In the second lexia, the expression of the meaning of denotation is, praying to be able to smile. In the connotation layer experienced a shift, the meaning contained in this lexia is the word "smile" has a positive feel or a happiness, people will smile if they feel happy. In this lexia has a connection with the first lexia, if connected, humans always hope to get happiness.

Lexia one and two are in the first stanza, so if it is concluded in the first stanza it has the meaning of contation, that is the human hope for happiness.

\section{3. 雨も降って涙も溢れる}

In lexia 3, the expression meaning denotation is rain falling and tears overflowed. In connotation, the connotation is experiencing a shift in meaning, namely rain is often confused with a somber thing, and moodiness. And tears are an expression of a human being if he feels sadness, in this lexia has meaning, sadness and depression will always be there to afflict this life.

\section{4. 夢}

In this 4th lexia expression of the denotation meaning is a dream. In the layers of meaning the experience shifts in meaning, which is something that is aspired to.

\section{5. 人生は紙飛行機願い乗て飛飛で行く}

In this lexia, the expression of the meaning of denotation is life is a paper airplane that brings hope flying. But in the layers of connotation there is a shift in meaning, that is, paper airplanes are portrayed like the way of human life. The paper airplane has a destination where it flies, but sometimes the airplane when flying can get to the destination we want but sometimes also the plane crashes before reaching the destination, or turn in another direction from our destination. This is the same as human life, sometimes we are happy because we managed to get what we want, sometimes we are also sad because our efforts failed. But in this fragile way of life, we always lean our hopes for ourselves.

\section{6. 風の中を力の限りただむむけ}

In lexia 6 the denotation expression is as fast as possible in wind. In the connotation layer the meaning changes, that is, whatever happens in our lives, it is still moving forward. 


\section{7. その距離を競うより}

In lexia 7 the denotation expression is rather than comparing the flight distance. The connotation layer experiences a shift in meaning compared to a person's age.

8. どう飛んだかどこ飛んののか

In lexia 8 the expression of denotation is how it flies and what it traverses. In the connotation layer experiences a shift in meaning, namely the purpose and how to live life. In lexia 8 has a connection with lexia 7 , that is if it is connected then, rather than comparing one's own age with others, we better see how a person lives his life. That will make us motivated to live life.

9. $365^{\prime \prime}$

At lexia 9 the expression of denotation is 365 days. In the connotation layer experiences a shift in meaning, namely, a long tempo of human life in life.

In lexia 5,6,7,8, and 9 constitute a unity in the 4th stanza if these 5 lexias are combined then the 4th stanza describes a way of life traversed by humans, which have twists and turns in it.

\section{0. 星はいくつ見える何も見えない夜か}

In lexia 10 the denotation expression is how many stars you can see, at night you can't see anything. In the connotation layer experiences a shift in meaning, that is, the subsidence of human life, sometimes has a direction and sometimes has no purpose.

\section{1.一人ぼっちじやない}

In this lexia the expression of denotation is not alone. In the connotation layer experiencing a shift in meaning, namely in life there are always others who can help us.

Leksia 11 has a connection with the previous leksia, that is, even though in this life we will face twists and turns, we always have other people who always help us.

\section{2. 自信 持って広 げる羽根}

In this lexia the expression of denotation is a wing that stretches with confidence. In the connotation layer experiences a shift of meaning, namely courage in living its life

\section{3. 折り方を知らなくても}

In this lexia the expression of denotation is even though it does not know how to fold it. In the connotation layer is experiencing a shift in meaning, namely, our ignorance in arranging this way of life. If it is associated with lexia 12 , it will produce courageous meaning to live this life even though we do not know how to arrange this way of life to achieve what we aspire.

\section{4. 希 望推進力}

In this lexia the expression of denotation is a driving force of hope. In the connotation layer experiences a shift in meaning, namely, the passion to achieve what we aspire. If this lexia is related to lexia 12 and 13, it will produce a meaning, that is, dare to live this life even though we do not know how to arrange this way of life to achieve what we aspire, it is precisely our passion to achieve what we aspire.

Leksia 12,13 and 14 become one unity in verse 7 , if combined, the 8 th verse has the meaning of courage in living this life. 
15. 飛んで行け! 飛んでみよう!

In this lexia the expression of denotation is fly! Try to fly! In the connotation layer experiencing a shift in meaning that is, just live this life never be afraid to fail.

After interpreting the above connotations, the meanings contained in each stanza are as follows

\begin{tabular}{|l|l|}
\hline Verse 1 & human's hope for happiness \\
\hline Verse 2 & sadness and melancholy will always be there to afflict this life \\
\hline Verse 3 & things that are aspired to \\
\hline Verse 4 & the way of life traversed by humans, which has twists and turns in it \\
\hline Verse 5 & the dynamics of human life \\
\hline Verse 6 & $\begin{array}{l}\text { although in this life we experience twists and turns, we always have other people } \\
\text { who always help us. }\end{array}$ \\
\hline Verse 7 & courage in living this life. \\
\hline Verse 9 & just live this life never be afraid to fail \\
\hline
\end{tabular}

\section{Conclusion}

Based on a two-stage analysis of Barthes's semiotics, we obtain the meaning contained in the lyrics of 365 song Nichi no Kamihikouki, which is a journey of human life that strives to achieve his dreams, to be happy and so on, but as long as we live this life we are twists and turns we will face it like failure and we will surely feel the depression, sadness and all kinds of ups and downs of life. But even so we must still be brave in trying, do not ever be afraid to be alone, because there are still people who will help us and also do not ever be afraid of failure, just live it, try it then surely someday we will get what we expect and that we aspire.

\section{References}

[1] Sulkifli and Marwati, "Kemampuan Menulis Puisi Siswa Kelas Viii Smp Negeri Satu Atap 3 Langgikima Kabupaten Konawe Utara,” J. Bastra (Bahasa dan Sastra), vol. 1, no. 01, 2016.

[2] R. Wellek and A. Warren, Theory of literature. Harcourt, Brace \& World New York, 1956.

[3] O. K. S. Zaimar, Semiotika dalam analisis karya sastra. PT Komodo Books, 2014.

[4] A. Sobur, Semiotika Komunikasi. Bandung, 2006.

[5] Y. Kusumarini, "Analisis Teks Dan Kode Interior Gereja Karya Tadao Ando" Church of the Light" Dan" Church on the Water"," Dimens. Inter., vol. 4, no. 1, pp. 38-48, 2006. 